Vol. 4, No. 1, 2017

https://doi.org/10.23939/eem2017.01.025

UDC 338.43: 658.4

\author{
O. Stets
}

$\mathrm{PhD}$ student

Ye. Krykavskyy

Doctor of Economic Sciences, Professor

Lviv Polytechnic National University

\title{
EFFECTIVENESS OF INNOVATIVE VALUE-ORIENTED MARKETING SOLUTIONS ON DAIRY MARKET
}

\begin{abstract}
It has been found that optimum distribution of incomes has undergone certain transformational changes in current market conditions. Thus, internationally, the largest share of income (60\%) is the salary, while in Ukraine it makes only up to $35 \%$ of the total income. Other $65 \%$ comes from other sources. The purchasing power of the population is an important factor. In general, it has been proved (based on the average salary) that Ukrainians spend more than $50 \%$ of their income on food.

Main suppliers and brands operating on the Ukrainian dairy products market (Molokiya $^{\mathrm{TM}}$, Yagotynske ${ }^{\mathrm{TM}}$, Bila Linia' ${ }^{\mathrm{TM}}$, Voloshkove Pole ${ }^{\mathrm{TM}}$, Slovianochka ${ }^{\mathrm{TM}}$, Activia ${ }^{\mathrm{TM}}, \quad$ Prostokvashino ${ }^{\mathrm{TM}}$, Galychyna $^{\mathrm{TM}}$ ) have been assessed under such criteria as target audience, consumption purpose and product value. It has been established that there is a segment of premium goods consumers on the milk market who are ready to pay more for high quality products.

The expediency of introducing non-traditional methods of competition on the fast moving consumer goods markets has been substantiated. The most common example of such market is the market of dairy products, which are reasonably priced and have high level of nutrients, ensuring proper, normalized human diet.

The effectiveness of implementing innovative solutions to the marketing-mix development has been identified, the solutions focusing on such human values as natural and healthy food, environmentally friendly attitude (Fresh Milk technology, Pure-Pak Sense Aseptic packing).

It has been established that due to active use and modification of traditional marketing tools, Ternopil Dairy Factory PJSC (Molokiya ${ }^{\mathrm{TM}}$ ) showed impressive results as for the market share and geographic coverage of the market. The basis of these decisions was valueoriented approach, i.e. focusing marketing activities not
\end{abstract}

only on the product and the customer, but also on the traditional human values that are often not directly related to any goods or consumers. These are the following three topical areas:

- in the product policy - creation and/or modification of the products included in the healthy food diet with maximum preservation of natural properties;

- in the distribution policy - dramatic shortening of the production-consumption cycle, resulting in a very slight loss of natural properties, thus, radical reduction of the requirements for protective functions of packaging;

- in the distribution policy - maximum convenience of dairy products complete use and packaging recycling.

Keywords: dairy market, marketing-mix innovative solutions, human values.

Formulation of the problem. Dairy market, as one of traditional world markets, is highly competitive and has a quick product turnover. During its formation, this market has been going through traditional stages of development, being a seller's and a buyer's market and experiencing occasional domination of either suppliers of raw milk or dairy producers or domination of consumer behavior, both current and potential. This market was the first to experience the onset of the next stage of development characterized by domination of human values associated with environmentally friendly attitude, care about own and public health, concern for future generations. Such important human values components as empathy, sufficient awareness of negative climate change and topical processes (phenomena), convenience, simplicity as 


\section{O. Stets, Ye. Krykavskyy}

well as consistency with own position and behavior also remain in the focus of attention. Therefore, the success of business in the market of dairy products in Ukraine actually depends on making nonstandard, innovative decisions aimed at creating additional consumer values, often being close to spiritualvalues. Despite the fact that the issues of development and improvement of the dairy products marketing have always been in the focus of scientific research, constant changes taking place on the market and the emergence of new customer segments require finding new marketing solutions for its specific components.

\section{Analysis of recent research and publications.}

A considerable amount of research has been conducted to study so called FMCG (Fast Moving Consumer Goods) markets; in Ukraine - markets of daily-demand goods). The research has been aimed at creating long-term competitive advantages, strengthening and maintaining the market position by the major market participants due to availability (for potential customers) of milk

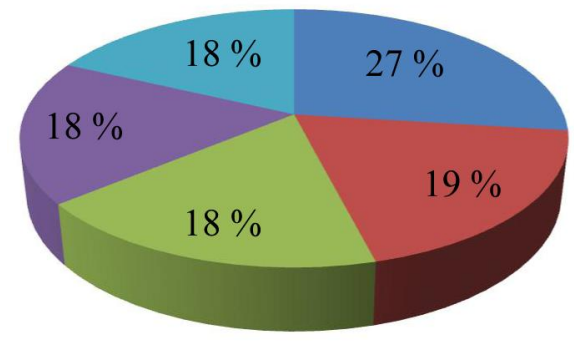

products, which are generated by dairy product producers, distributors and retailers. The most important scientific results have been presented in the studies of P.S. Berehivskyi [1], S. V. Vasylchak [2], O. K. Shafaliuk [3, 4], E. V. Krykavskyi $[5,6,7]$, N. S. Kosar [6, 7], N. R. Kubrak [5, 7], O. Yu. Bochko [8], L. Ya. Yakymyshyn [9].

The purpose of the research is to substantiate the necessity of making valueoriented marketing solutions on the dairy market as part of FMCG market.

Materials and results. Foodstuffs are the most necessary things for healthy life of a human. However, their quality and taste must meet established standards and needs of consumers. In general, (based on the average salary), it has been proved that Ukrainians spend more than $50 \%$ of income on food. As of the second quarter of 2016, after buying essential commodities $75 \%$ of the population still has some money that they spend mostly on clothing and outside leisure activities (Fig. 1).
- Clothing

- Outside leisure activities

a Loans repayment

- Savings

- Household refurbishing

Fig. 1. Distribution of people's income after buying essential commodities, \%

Source: [10]

Currently two methods for evaluating the distribution of people`s income are used:

1) income-based method measures distribution relatively to income and capital accumulation that are actually combined by the accumulated capital dynamics equation and characterized by the following formula:

$$
\frac{d K}{d t}=r K+y(t)-c(t),
$$

where $y(t)$ is income at $t$ time; $c(t)$ is consumption at $t$ time; $K(t)$ is capital at $t$ time; $r$ is interest rate on capital; $d K / d t$ is the derivative from capital over time;

2) expenditure-based method measures the maximum amount of money, which an individual can spend during the month when the research is done.

While the first method is based on how much money must be spent, the second one represents how much people can spend for consumption. We can say that optimum distribution of incomes has undergone certain transformational changes under 


\section{Effectiveness of Innovative Value-Oriented Marketing Solutions on Dairy Market}

current market conditions. Thus, internationally, the largest share of income is the salary, while in Ukraine it only makes up $35 \%$ of income. The rest accounts for additional income, making the main basis of people's purchasing power. As for most European countries, the share of salary in the overall income is more than $60 \%$.

Now Ukraine is still one of the most pessimistic countries in the world. In addition, it occupies the $16^{\text {th }}$ position in the rating of countries in terms of retailers' share in the total sales of the country (Fig. 2).
The most common products on fast moving consumer goods market are dairy products, which are reasonably priced and have high level of nutrients, ensuring proper, normalized human diet. Major suppliers of dairy products to fast moving consumer goods market in Ukraine are Molokiya $^{\mathrm{TM}}$, Yagotynske ${ }^{\mathrm{TM}}$, Bila Linia ${ }^{\mathrm{TM}}$, Voloshkove Pole ${ }^{\mathrm{TM}}$, Slovianochka ${ }^{\mathrm{TM}}$, Activia ${ }^{\mathrm{TM}}$, Prostokvashino $^{\mathrm{TM}}$, Galychyna ${ }^{\mathrm{TM}}$, which are presented in Table 1.

Fig. 3. shows the share of these brands within the studied market.



$\square$ Share of retailers in the total turnover of the country, \%

Fig. 2. The share of retailers in the country turnover, \% 
O. Stets, Ye. Krykavskyy

$\frac{\sqrt{0}}{\frac{0}{0}}$

\begin{tabular}{|c|c|c|c|c|c|}
\hline 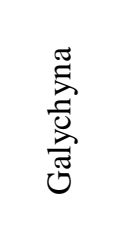 & 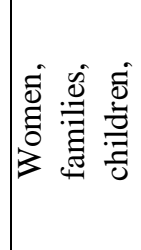 & 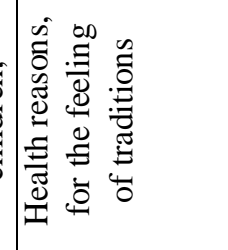 & 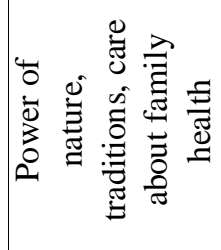 & 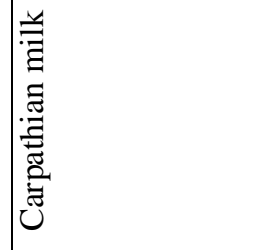 & 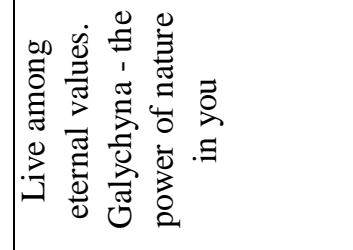 \\
\hline$\frac{\frac{\pi}{0}}{\frac{0}{0}}$ &  & 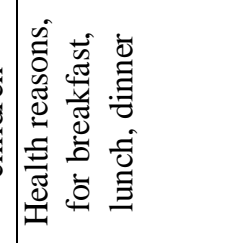 & 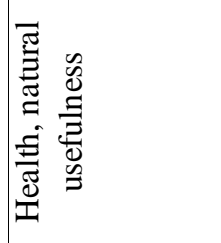 &  &  \\
\hline $\begin{array}{l}\stackrel{0}{\Xi} \\
\frac{1}{0} \\
0 \\
\frac{1}{0} \\
0 \\
0 \\
0 \\
0\end{array}$ & 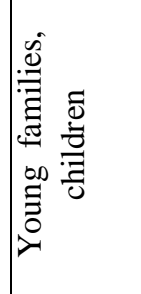 & 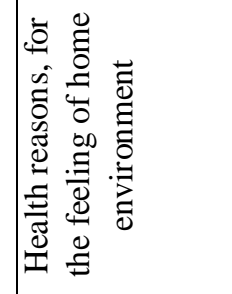 & 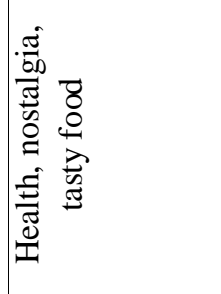 & 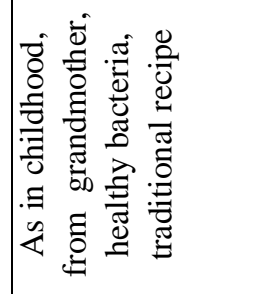 & 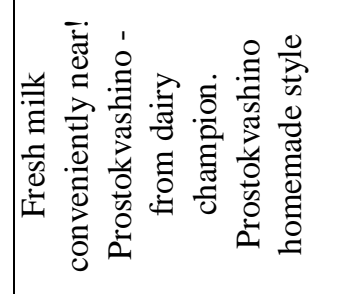 \\
\hline : & 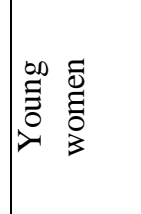 & 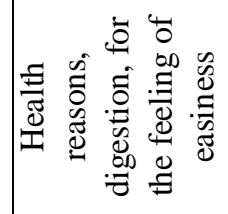 &  & 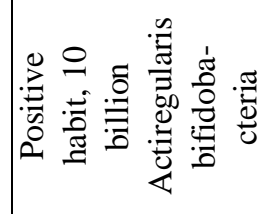 & 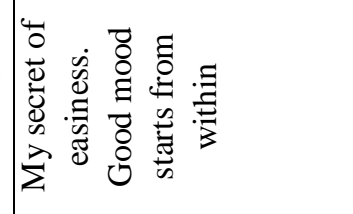 \\
\hline 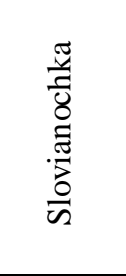 &  & 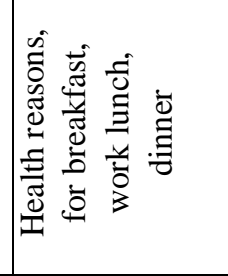 & 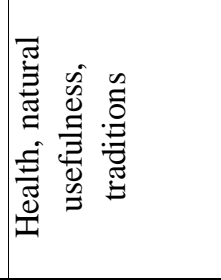 & 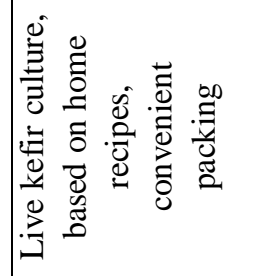 & 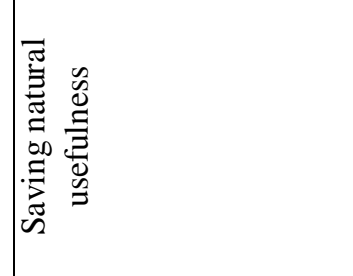 \\
\hline $\begin{array}{l}\frac{0}{2} \\
\frac{0}{0} \\
\frac{1}{0} \\
\frac{0}{0} \\
0 \\
0\end{array}$ & 兽这 & 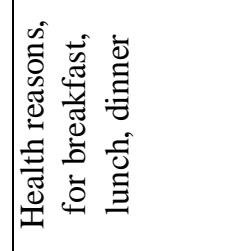 & 童泀 & 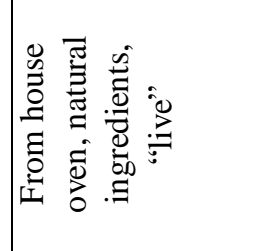 &  \\
\hline 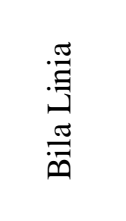 & 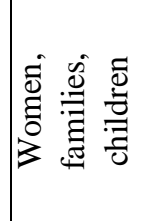 &  & 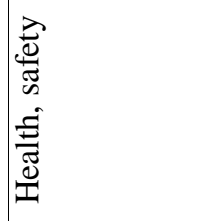 & 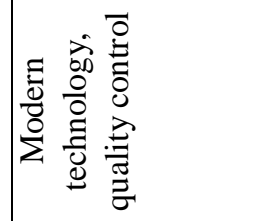 & 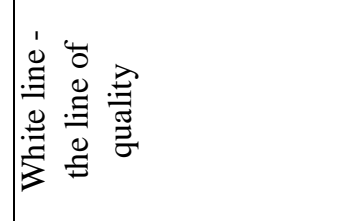 \\
\hline 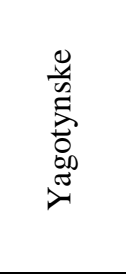 & 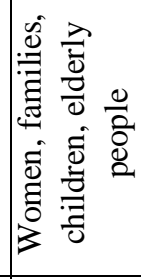 & 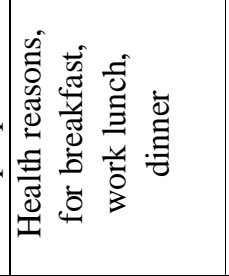 & 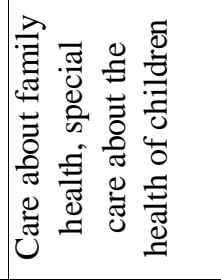 & 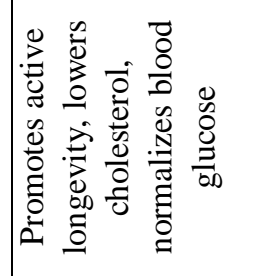 & 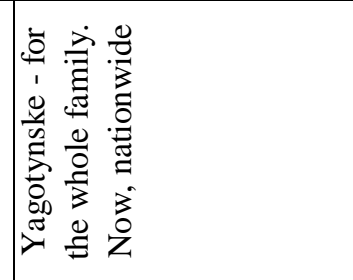 \\
\hline 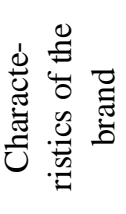 & 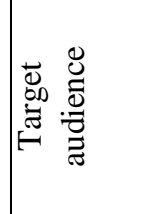 &  & : & 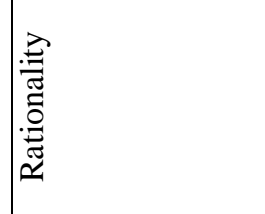 & 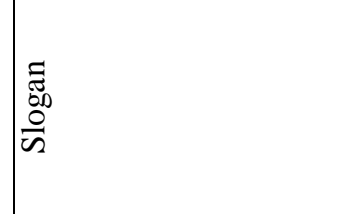 \\
\hline
\end{tabular}

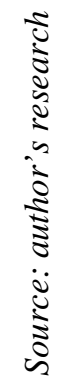




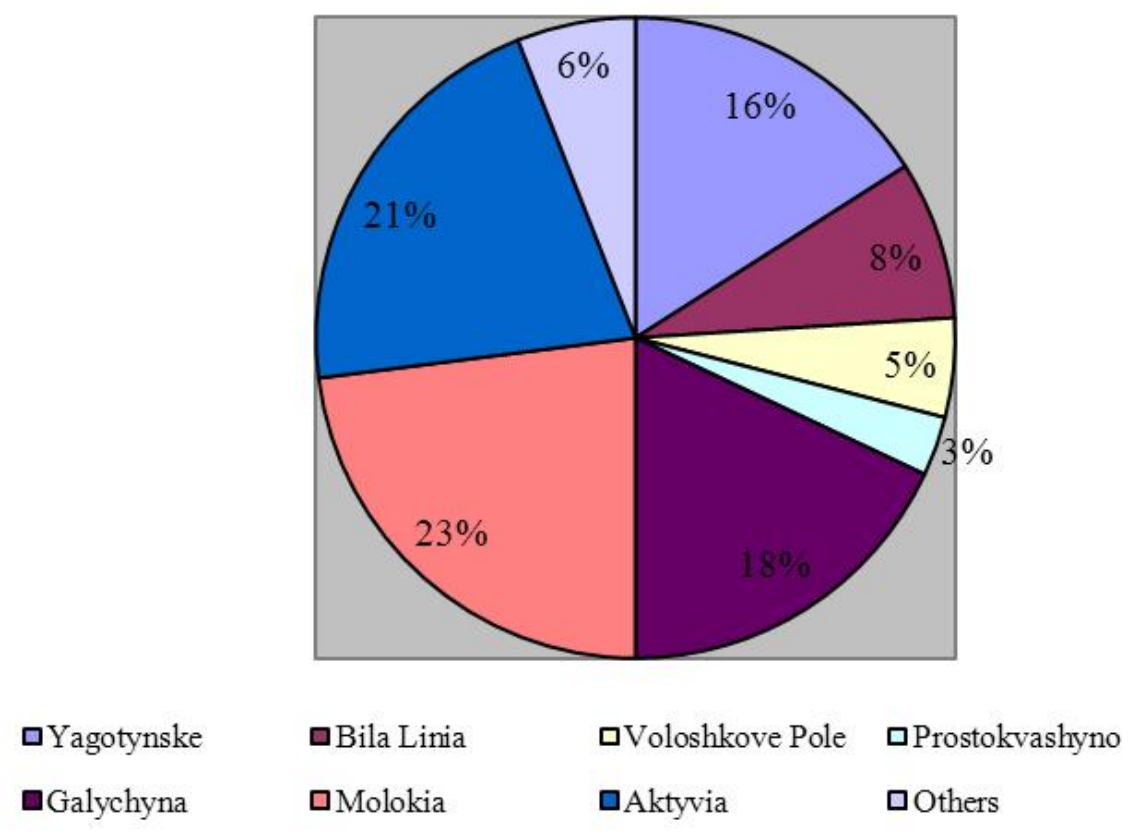

Fig. 3. The share of major dairy brands

on the fast moving consumer goods market of the Western region

Source: based on the author's research

Ternopil Dairy Factory PJSC (Molokiya ${ }^{\mathrm{TM}}$ ) is one of Ukrainian companies operating on the retail market that has been effectively and dynamically developing for the past 20 years producing natural and healthy dairy products. Basic company product is milk which is produced by Fresh Milk technology, preserving its natural taste and useful properties.

Due to active use and modification of traditional marketing tools the company showed impressive results as for the market share and geographic coverage of the market. Following are the key factors of such success: first of all, the basis of the company development is valueoriented approach, i.e. focusing marketing activities not only on the product and a customer, but also on the traditional human values that are often not directly related to any goods or consumers. These are three topical areas:

- in the product policy - creation and/or modification of the products included in the healthy food diet with maximum preservation of natural properties;

- in the distribution policy - dramatic shortening of the production - consumption cycle, resulting in a very slight loss of natural properties, thus, radical reduction of the requirements for protective functions of packaging;

- in the distribution policy - maximum convenience of dairy products complete use and packaging recycling.

It should be noted that implementation of these issues enables increased affordability of dairy products as it is directly reflected in the cost of production and distribution, promoting environmental consciousness, facilitating introduction of environmentally friendly consumer behavior in the context of package management.

Currently Ternopil Dairy Factory PJSC pays special attention to health. The main goal of all brands without exception is improving the health of their consumers.

The current paradigm of healthy food observed now is its naturalness. The basic principles of Molokiya ${ }^{\mathrm{TM}}$ are still fresh, straight from the garden with minimum processing! One of the main goods produced by the company, which we study in our research, is milk, which is a consumer food product sold on a daily basis and regardless of the economic situation in the country. However, not all buyers like the taste of pasteurized milk in ordinary packaging. Many 
people go to the village in order to buy fresh milk or purchase it from farmers' barrels, which is not very convenient. A trip to the village takes time, and usually the barrels are brought only on certain days; besides, the quality of milk from the barrel does not always meet hygienic standards.

The way out of this situation was found by Ternopil Dairy Factory PJSC which was the first company in Ukraine to introduce a European Fresh Milk standard. It preserves the natural structure of milk and its useful properties. In this regard, the amount of ultra-pasteurized milk in Ukraine in 2016 rose by $28 \%$ compared to 2015 [12]. Today $60 \%$ of Ukrainian consumers prefer premium products, i.e. the products which cost about $20 \%$ more than the products of average price. As for dairy products, it is $32 \%$ of consumers who are willing to pay more for the proper quality products [13]. Increased demand for more convenient packaging led to the market growth of small size milk cartons. In this regard, Ternopil Dairy Factory PJSC started using Pure-Pak Sense Aseptic cardboard packing, which combines both design and functionality: it is easy to fold, easy to compress the package to pour out remaining milk, which helps to reduce food waste. Furthermore, the possibility to fold the packaging reduces the volume of waste to be transported and recycled.

Asymmetric top of the packaging allows using packaging of various sizes, while its attractive elegant shape improves brand image on the shelves of the supermarkets. Upper edge enables printing for better orientation and providing information about the benefits of the product as well as placing advertising messages. New Pure-Pak Sense Aseptic packaging is the latest innovation of Elopak research and development department, which is constantly designing something new to improve cardboard packaging and increase its added value. In addition, the company launched a line of small size thin beverage cartons in order to meet current market demand for small and convenient packaging. PurePak Sens Aseptic cartons are intended for dairy products and have a base area of only $47 \times 32.5 \mathrm{~mm}$, making the packaging look very slim. Cartons range in size, having 7 packaging volumes: $80 \mathrm{ml}$,
$90 \mathrm{ml}, 100 \mathrm{ml}, 110 \mathrm{ml}, 125 \mathrm{ml}, 150 \mathrm{ml}$ and $180 \mathrm{ml}$. All of them are suitable for the same SIG Combibloc filling machine.

Thus, Ternopil Dairy Factory PJSC is one of the promising companies that seeks to improve public health.

Activia $^{\mathrm{TM}}$ has the second biggest share on the dairy products market. The basic principle of the trademark under study is to get a good mood that starts from the inside.

Under the conditions of falling prices for milk and its increased supply, producers are forced to seek alternative markets and sales methods, resorting to automated selling of milk through vending-machines. Milk vending machines open up new business opportunities: buyers prefer quality affordable milk, thus investing in the dairy business results in rapid payback and profit growth. Consequently, the implementation of such an innovative project provides the opportunity to buy fresh milk near the house.

In the countries of America and Europe milk has been sold through vending machines for a long time. Such way of selling has become common, and milk business has become quite profitable. In the post-Soviet countries this business is completely undeveloped, although the investment is fully returned after a couple of months.

Main advantages of using milk vending machines for customers are:

- possibility to buy fresh milk quickly, at any time and without waiting in a line, close to one's home;

- availability of only high-quality milk delivered directly from the farm, with $3,7-4 \%$ of fat, which makes it possible to use it for making cheese, yogurt, and sour cream;

- the price of tap milk is significantly lower than the price of the milk in cartons due to direct sale, significant reduction of packaging costs and absence of the vendors' pay;

- the machine preserves the taste and aroma of fresh milk;

- this method of selling complies with all hygiene standards.

Use of milk vending machines, where this good quality product can be purchased at a low price, results in increased product demand and turnover growth. Location of other consumer goods 
next to milk vending machines will definitely increase sales, as together with milk buyers are likely to buy bread, pastry, cakes and other products from the range of food store.

As seen from above, purchasing of milk vending machines is a good investment for modern farms, which can provide them with steady income and rapid payback.

The first milk vending machine made by Swiss company BRUNIMAT GmbH appeared in Ukraine in the city of Uman in summer 2012 on the initiative of AVM Milk Producers' Association. At first, the citizens of Uman were surprised by the machine but it quickly gained popularity. Not surprising is the fact that the second milk vending machine was put into operation by AVM in October. Uman was not alone in this endeavor: automated points of milk sale appeared in other cities. Thus, spearheaded by AVM, they have been functioning in Odessa and Kirovograd regions. In current conditions, with the help of milk vending machines, Ukrainian farmers are trying to eliminate intermediaries in the chain of sales, relying on selling milk directly to consumers through such vending machines.

Conclusions. As a result of the study it was found that the quality of dairy products plays a special role on the fast moving consumer goods market. It was shown on the example of Ternopil Dairy Factory PJSC - the company that produces natural and healthy dairy products. The prospects for the development of the company in the present circumstances is to improve the quality of its products and to provide 24/7 availability of fresh goods for the public. Some steps have already been taken in this direction. Thus, the company has launched a new type of packaging - Pure-Pak Sense Aseptic. In order to provide availability of fresh milk around the clock, it is proposed that dairy enterprises use milk vending machines, which is a promising innovative way to expand their business.

\section{References}

1. Berehivskyy, P. S. \& Zheleznyak, A. M. (2008). Konkurentospromozhnist molokopererobnykh pidpryiemstv: teoriia, metodyka, praktyka [The competitiveness of dairy enterprises: theory, methodology, practice]. Lviv. [in Ukrainian].

2. Vasylchak, S. V. (2005). Formuvannia ta rozvytok rehionalnoho rynku moloka $i$ molochnykh produktiv [The formation and development of the regional milk and dairy market: monograph]. Lviv: Scientific-Production Enterprise "Ukrainian Technologies". [in Ukrainian].

3. Shafalyuk, O. (2009). Modern approaches in optimization of assortment portfolios and the brands architecture of enterprises on the example of the dairy industry. Marketing in Ukraine [Marketing in Ukraine] 6, 49-58. [in Ukrainian].

4. Shafalyuk, O. (2008). Reserves for the demand growth and efficiency of marketing activities in the markets of dairy products]. Marketing in Ukraine [Marketing in Ukraine] 4, 12-18. [in Ukrainian].

5. Krykavskyy, e. V. \& Kubrak, N. R. (2010) The current accents of the formation of enterprises' competitiveness. Visnyk Khmelnytskoho natsionalnoho universytetu: ekonomichni nauky [Herald of Khmelnytsky National University: Economics Herald of Khmelnytsky National University: Economic Sciences] 3, 54-57. [in Ukrainian].

6. Krykavskyy, Ye. V. \& Kosar, N. S. (2012). The formation of marketing strategy of industrial enterprise. Menedzhment ta pidpryiemnytstvo $v$ Ukraini: etapy stanovlennia i problemy rozvytku. [Management and entrepreneurship in Ukraine: stages of formation and problems of development] Lviv, 748, 357-361. [in Ukrainian].

7. Kubrak, N. R., Krykavskyy, Ye. V., \& Kosar N. S. (2013). Potentsial elastychnosti u formuvanni konkurentospromozhnosti promyslovykh pidpryiemstv [The potential of elasticity in the formation of the industrial enterprises' competitiveness: monograph]. Lviv: Lviv Polytechnic Publishing House, 2013. (Series "The world of marketing and logistics", 4). [in Ukrainian].

8. Bochko O. Yu. (2016). The current state of volumes of dairy production in Ukraine. International scientific journal, 2016. 9, 13-15. [in Ukrainian].

9. Yakymyshyn L. Ya. (2015). Strategic dimension of logistic operators in supply chains of products of daily demand. Economic Analysis: Sb. sciences works. Ternopil: Publishing and Printing Center of Ternopil National Economic University "Economic Thought”. V. 21, 2, 238-244. [in Ukrainian].

10. Na chomu ekonomliat Ukraintsi? [How do Ukrainians economize?]. (2017). Retrieved from 


\section{O. Stets, Ye. Krykavskyy}

http://www.nielsen.com/ua/uk/insights/news/2016/ CCI-Q2.html [in Ukrainian].

11. Global powers of retailing (2017). Retrieved from http://www2.deloitte.com/uk/en/pages/consumerbusiness/articles/global-powers-of-retailing.html

12. V Ukraini stvoryly mapu yakisnoho moloka [A map of high-quality milk was created in Ukraine]
Retrieved from http: //a7d.com.ua/novini/35524ukrayina-zblshila-eksport-molochnih-produktv. html [in Ukrainian].

13. Premialni tovary abo smak harnoho zhyttia [Premium goods or a taste of a good life] Retrieved from http://www.nielsen.com/ua/uk/insights/ news/2016/premiumization.html [in Ukrainian]. 